\title{
Making Ripples and Waves through Feminist Knowledge Production and Activism
}

\author{
by Lea Skewes, Molly Occhino \& Lise Rolandsen Agustín
}

\begin{abstract}
"A feminist movement is a collective political movement. Many feminisms mean many movements. A collective is what does not stand still but creates and is created by movement. I think of feminist action as ripples in water, a small wave, possibly created by agitation from weather; here, there each movement making another possible, another ripple, outward, reaching." (Ahmed, 2007, 3)
\end{abstract}

We took on this special issue "\#MeToo, Discrimination and Backlash" in order to draw attention to different feminist researchers' and activists' efforts to start these ripple effects within their field and within their worlds. We wanted to help them grow their ripple effects into larger waves, making the rings of the ripples reach even farther. But we also wanted to draw attention to how feminist knowledge production often comes up against institutionalised backlash or brick walls (Ahmed 2017).

Ahmed's concept of brick walls captures that institutionalised habits and norms can become cemented to such an extent that challenging them feels like banging your head against a brick wall. This is, unfortunately, a common experience amongst many feminist researchers and activists. We aim to discuss this cementing of institutional habits into brick walls, and the affective experiences of coming up against them. We wanted not only to trouble institutionalised habits and norms (Butler 1990; Ahmed 2017), but also to stay with that trouble (Haraway 2016) as a collective political movement advocating for change.

The base assumption of this special issue is that feminists' come up against brick walls when fighting for greater inclusion of women, people of colour, trans or queer people; and that this struggle typically has been met with backlash. Often the backlash has been especially harsh when people with minority identities have explicitly challenged currently privileged people. Therefore, the explicit challenge to privileges is central to this special issue. We hope to strengthen the academic voices which challenge patriarchal, masculine, white, cis-, and heteronormative norms, which for so long have been the invisible backdrop from which everyone else in academia has been cast as deviant outsiders (Ahmed 2012; Butler, 1990; Crenshaw, 1989). Therefore, we strive to bring out the internal conflicts and discriminatory processes within knowledge production in academia, and feminist activism more broadly, in order to create knowledge production spaces which are more inclusive, giving voice to many feminisms.

Therefore, we invited articles and essays from people who engaged with \#MeToo, sexual assault, and feminist activism inside and outside of academia. We invited people to describe their own experiences, shaped by their own positionality, in order to capture the backlash they have come 
up against when they dare to challenge academic or societal norms. This resulted in work by people who challenged sexism, racism, colonialism, heteronormativity and cis-/hetero-normativity. The intention was to invite researchers and activists to join us in a collaborative killjoy effort (Ahmed 2010) in which we present how researchers and activist name, reflect upon, and fight against these cemented discriminatory processes both in academia and society at large.

As an editing team and in our academic work, we embrace the interpellation of us as trouble makers or feminist killjoys (Ahmed 2010, 2017), but insist on causing trouble by consistently addressing biases, discrimination and normative judgements within knowledge production and social practices. We want to insist on speaking openly about different types of feminist knowledge production which are highly controversial and therefore exposed to intense backlash and cemented institutional habits experienced as brick walls. We want to do this, because addressing these problems and staying with the trouble, is the first necessary step towards creating more liveable worlds (Ahmed 2017; Haraway 2016).

\section{The Revolutionary Wave of \#MeToo}

We believe that feminist knowledge production can have revolutionary potential, and we wish to tap into this potential by letting important feminist stories be told. One of the most revolutionary types of knowledge productions that has taken place within recent years is women starting to document and stand up against sexism and sexual harassment. Laura Bates' (2014) Everyday Sexism Project was the first global campaign to systematically document the problem. She simply asked people to upload their personal experiences with everyday sexism, which ranged from cat calls to sexual assault. Naming the problem has the potential to be revolutionary!

A similar idea was initiated by Tarana Burke, a Black American woman who created the hashtag \#MeToo in order for victims of sexual harassment and sexual assault to share their experiences.
The hashtag, however, did not go viral until it was picked up by the white Hollywood actress Alyssa Milano, who encouraged others to use the hastag in order to document the extend of the problem (Mendes, Ringrose, \& Keller 2018). Immediately after this re-launch of the hashtag, initiated by a white celeberty, it was used 12 million times within 24 hours (CBS 2017). The \#MeToo hashtag thereby helped to document that destructive gendered dynamics are at play everywhere in society, all over the world, and amongst all people.

The \#MeToo revolution has been very slow to hit Denmark. However, since tv-host Sofie Linde's speech at the Zulu's Comedy Galla in August of this year, the floodgates have been opened, and Denmark has entered into a wave of \#MeToo reports. Employees in the Danish media, politicians, doctors, academics and others have followed suit - all telling stories which reveal major challenges with sexism and sexual harassment in Danish workplaces (Astrup \& Jensen 2020). High profile politicians have stepped down from their positions after women have come forward with their experiences of being sexually harassed by them. In other words, Denmark has just started riding a \#MeToo wave similar to the wave many other countries were caught up in a couple of years ago. The perpetrators are now being called out for their actions, and victims are finally starting to be heard and supported by many.

It is important to celebrate feminist waves in all shapes and sizes. This revolution has definitely offered greater room for people, especially women and other minoritised people, to speak up against sexism and sexual harassment by using the \#MeToo hashtag. However, we must also make sure that we dare to stay with, and learn from, the type of resistance this type of progress comes up against. We need to pay serious attention to the fact that when gathering these stories of sexism and sexual harassment, both Bates and Burke also documented silencing strategies. These silencing strategies are put in play in order to deny or delegitimise victims stories about sexism and harassment, thereby ensuring that victims are not heard, and problems are not addressed. These findings bring to our attention that not talking about the 
problem of sexism and sexual harassment, ironically, is at the core of the problem (Bates 2014; Skewes, Skewes, \& Ryan accepted). Brick walls can also manifest themselves as silence. However, it is key that we speak up and demand to be heard even when we are met by silencing strategies. Telling our collective stories and labelling them discrimination (revealing the extent of the problem) has proven to be a very important first step in the feminist revolution.

The ripples of individual voices have collectively become waves which have started breaking down the postfeminist fantasy (Ahmed 2017, 5); the fantasy that there are no sexism problems left to solve in academia or in our culture. The wave of collective voices has oriented more and more people toward a realisation that we need to fight for structural change. Maintaining the status quo is not an acceptable option. Until recently, many non-feminist Danes might have bought into the postfeminist fantasy, and therefore believed that sexism and sexual harassment were relatively minor problems, or that it had already been solved. However, inside feminist research circles this has never been the case; feminists have worked hard to convince others of the (continued) existence of sexism, racism, homo- and trans-phobia (Ahmed 2017; Butler 1990).

In 2018, Dahlerup revealed that around onethird of Danish Members of Parliament (MPs) believe that no further interventions are needed to achieve gender equality. In other words, many MPs believe that we already have entered this postfeminist utopia of gender equality. Similarly, $\mathrm{H} \varnothing \mathrm{g}$ Utoft (2020) documented that Danish academia was not the postfeminist utopia many expected it to be. Skewes, Skewes, \& Ryan (2019) uncovered a worryingly high degree of modern sexism - the denial of the need for interventions against sexism (Swim et al., 1995) in Danish academia. Furthermore Skewes, Skewes, \& Ryan (accepted) linked academic's modern sexist attitudes to attitudes towards \#MeToo, and showed that academics with higher modern sexism scores are more likely to be negative or outright hostile about the movement, compared to academics with less modern sexist attitudes. The same study also shows that the most prominent theme capturing university employees' attitudes about the \#MeToo movement concerns silencing strategies, suggesting that many academics still are not ready to hear about co-workers' experiences with sexism and sexual harassment. This of course means that we have to keep staying with the trouble, to reveal the brick walls we are coming up against in our feminist struggles to achieve equity.

We do not have to be alone with our experiences of sexism and sexual harassment. We can find strength in sharing, and in becoming a collective of voices speaking up. Unfortunately, some people's inability to react with recognition and empathy to these stories reveals that structural gender inequalities still do persist (Borchorst and Rolandsen Agustín 2017). The brick walls are still there. Not everyone is ready to listen. However, as the second wave of the \#MeToo movement in Denmark shows, a stone thrown causes ripples, it causes movement, it moves us, and the movement of people siding with the victims and killjoys is growing larger every day. Putting a name to the problem and staying with the trouble can start to make lives and worlds more liveable.

While we celebrate the progress that both the Everyday Sexism Project and the \#MeToo movement has paved the way for, it is also important to be attentive to which voices are offered most speaking time within and through these movements. The experiences of women of colour and indigenous women, trans and queer people, people with disabilities, and other marginalised identities are often excluded. This inability to hear certain voices within the movement has resulted in white, cis-, heterosexual, upper/middle-class women dominating many of the discussions. Phipps (2019) uses \#MeToo as an example of a movement which has co-opted the work of women of colour and other minorities. This co-opting of Black women's work was exemplified in the media visibility of \#MeToo, where white Hollywood actresses' experiences became highly visible with the Harvey Weinstein trial. Similarly, when the \#MeToo founder Tarana Burke and actress Alyssa Milano were interviewed on the Today show together, Milano was criticised for not 
only interrupting and talking over Burke, but also taking up most of the airtime (Phipps 2019). This teaches us that we also need to be willing to be attentive to the discriminatory processes within our feminist movements. We need to keep insisting that multiple feminist voices are invited in and heard in our collective revolutionary spaces.

\section{Who fits comfortably into academia and academic knowledge production?}

The \#MeToo movement brings home that knowledge is power which can reshape the world. The ripples of individual stories about sexism and sexual harassment have grown into a wave of collective stories, which have clearly had a revolutionary impact. The Everyday Sexism Project and the \#MeToo movement, have extended the reach of feminist waves by using their platforms to show how all-encompassing gendered violence is. One example of the potential power of such waves is documented by Levy \& Mattson (2019) who shows how the increase in awareness of the problems which has been achieved through the \#MeToo movement has led to an increase in reporting of sexual crimes to the police. When we put a name to the problem, and insist that our voices are heard, we can turn little ripples into waves using the new collectively produced knowledge to push for further structural change. Thus, we need to keep pointing to the problems captured in our collective stories of oppression. We need to stay with the trouble until we see the necessary structural changes. The wave of the \#MeToo movement shows us that knowledge holds an agentic potential to reshape both our worlds and the subjects in it.

However, exactly because knowledge is power, the rights to knowledge and knowledge production has always been policed extensively. A significant part of this policing has been gendered (Possing, 2018) and racialised (Ahmed 2017). In the last 50 years, feminist knowledge production has concerned itself with questions of power within knowledge production and the political entanglements of knowledge production and knowledge producers (Anzaldúa \& Moraga 1981; Ahmed 2012, 2017; Butler 1990; Collins 1989, 1990; Haraway 1988, 2016; Haraway \& Goodeve 1997; Stryker 1998, 2006; Spivak 1981, 1998). These questions have centred around; Who produces knowledge for whom? Who is the research subject/object and what degree of agency are the subjects offered in the process? Who does the knowledge production empower? And from which status position is the knowledge produced and disseminated?

These kinds of questions draw attention to the notion of objectivity, and the absence of self-positioning in a lot of academic knowledge production. One of the most famous critiques of the disembodied research stance is captured by Haraway's notion of the God trick (1988) - the absent all-seeing eye/l (1989). With this notion, Haraway discusses the idea of the faceless, bodiless and contextless knower as an illusion which hides the knowledge producers and their particular power positions (1988). In contrast to this positivist notion of objectivity, feminist theory has striven to draw attention to the male, white, straight, cis-, able-bodied researcher as the normative embodiment of objectivity (Ahmed, 2012; 2017; Butler, 1990; Haraway 1988, 1997, 2016; Stryker 2006). We need to keep drawing attention to the fact that non-situated knowledge production maintains the status quo's power hierarchies. We need to speak openly about who is facilitated in our academic institutions and who therefore sinks comfortably into the academic work environment, at the expense of others (Ahmed, 2007, 2017).

Feminist challenges to the illusion of a neutral or objective stance have also led to critical self-reflection within feminist research. Multiple diverse researchers have criticised exclusionary and discriminatory processes and practices within the discipline of feminist research, often driven by a privilege blindness to multiple intersecting social category positions. For instance, the most famous queer-theorist Butler (1990) pointed out the hidden heteronormative assumption in standpoint feminism, which excluded non-heterosexual 
women from the scientific discourse. Early decoIonial and Black feminists such as Collins (1990, 1998), Mohanty (1988), Anzaldúa \& Moraga (1981), and Spivak (1991, 1998), have criticised how white Western women's voices typically are the ones being heard in feminist research at the expense of Black voices, Indigenous voices, and the voices of people of colour. Within transfeminist studies, Namaste (2000) and Prosser (1998) authored some of the earliest critiques of feminist queer studies for only using trans people as props to hold up their theories, while ignoring the lived experiences and realities of trans people. Joining these critiques, researcher such as Enke (2012), Halberstam (2017), Raun (2014), Stone (1987), and Stryker $(1994,1998,2006)$, have pushed back against the problematic discourses of trans-exclusionary radical feminists, and feminists engaging with trans people's lived experiences in problematic ways.

Feminist scholars existing in the margins have therefore used their scholarship to call for greater inclusion in the scientific communities, and have called for critical but "respectful engagement" (Raun 2014) with subject matter about marginalised peoples' lives and bodies. In other words, scholars embodying multi-layered troubled subject positions (Staunæs 2005) have drawn attention to the different kinds of normative structures within academia. In this special issue, we want to open feminisms up, thinking about feminisms in a pluralist fashion. Thus, we want to connect with other feminist thinkers and genealogies (Halberstam 2017, 110), in order to build other liveable worlds and more liveable lives (Haraway 2016).

\section{Born unfit for academia and knowledge production?}

Often arguments against the inclusion of women, people of colour, and trans and queer people has been entangled in essentialist arguments. For example, the arguments against women's access to knowledge and knowledge production has been based on gender essentialist and heteronormative assumptions: that (cis-)men and (cis-)women biologically are programmed fundamentally differently. Arguments of this kind typically rely on the premise that women are biologically wired to take on tasks which situate them in the home in a caring, facilitating role to both men and children. Men, on the other hand, are considered biologically more rational and strong and thus equipped with abilities that make them superior at shaping and controlling the world outside the home (for information on the positive correlation between gender essentialist beliefs and the support of gender discriminatory practices see Skewes, Fine \& Haslam, 2018 and for historical examples of this type of arguments see Possing 2018). Similarly, Black and decolonial feminisms have criticised how essentialist arguments have been used against people of colour, by positioning white Western people as the superior race. For instance, Mohanty (1988) shows that white Western feminist research often has cast "Third World Women" as essentially inferior to Western women defining them as: poor, uneducated, tradition-bound, domesticated, family-oriented, and victimised.

While many women, people of colour, and trans and queer people have entered university settings, we have never quite moved beyond the argument of the deficiency of minorities within academia. For instance, Nielsen (2017) documents that Danish universities stand out in comparison to Swedish and Norwegian universities' approach to gender equity, by often relying on a 'fixing the women' approach. That is, women's lack of progress in academia is still often attributed to their gendered inadequacies, rather than structural discriminatory practices or sexist institutions. The universities have striven to compensate for these expected deficiencies by offering special training courses for women; even though we know from other sectors that training aimed at addressing assumed 'individual characteristics' rather than structural barriers tend to exacerbate the problems (Piscopo, 2019). In other words, the 'fixing the women approach' does not fix the core underlying structural problems of academia and institutionalised knowledge production. 
Similarly, pointing to troubled access for people of colour in academia, Shardé Davis and Joy Melody Woods started the hashtag \#BlackInThelvory documenting how being a Black women in research exposed them to racism at many different levels. This hashtag illustrates that some researchers come up against brick walls when they are just trying to carry out their research. Both the example of 'fixing the women' and the BlackInTheIvory hashtag illustrate that not all subject positions are a comfortable fit in academia - some are assumed deficient simply because they do not fit the traditional mold of the knowledge producer. In other words, these examples illustrate that knowledge production still remains rooted in patriarchal and racist assumptions which have become institutionalised. In order to stay with the trouble, we need to do the kind of research that can create waves that can trouble and dismantle the current oppressive structures which are blocking people from entering universities. We need to keep insisting on producing knowledge from different and diverse subject postions.

Just like a feminist revolutionary potential was unleashed when we started sharing our stories from all our unique and intersectional subject positions (Staunæs 2005) under \#MeToo, we share a hope that academia and academic voices will increasingly become more and more diverse. We hope to achieve this by speaking out against the brick walls faced both in and outside of the ivory tower. As a part of this practice, we argue that we need to create a space where we can speak about who is facilitated by the university, as well as its hegemonic definitions of 'legitimate' and 'objective' science. We argue that we need to facilitate knowledge production taking place from many different subject positions. We need multiple ways of pushing back against hegemonic understandings of which kind of research is the most 'legitimate' or 'objective' form of knowledge production. If we want to fight the 'patent' to knowledge production currently held by the all-seeing eye/l (Haraway 1989) of the unspecified male, white, Western, straight, cis-, and able-bodied researcher, we need to stay with the trouble by tracing, and picking apart different threads (Haraway 2016) of the fabrics of the power structures that lay under the academy. Thus, we must trouble the making and unmaking of knowledge production. In doing so, we must ask: Who are we currently orienting the universities towards? How and why are we orienting the universities in this way? If we dare to make such trouble, and trouble; ourselves, the research, and the research institutions, then we can start to re-orient ourselves and our institutions and thereby facilitate a change in perspective. This type of troubling can help us re-think who can produce legitimate knowledge; whose world perspective knowledge ought to include; and what knowledge production could and should look like in the future.

\section{Overview of the contributions for}

\section{this special issue}

In this special issue, we start out with an interview with Professor of Political Science at Stockholm University and Honorary Professor at the Centre for Gender, Power and Diversity at Roskilde University Drude Dahlerup. Under the title of "Feminist Research in Misogynistic Times" she lays out her international perspective on the current political climate where politics of sexism, homophobia, and xenophobia are dominating the political stage inside countries such as USA, Brazil, the Philippines, Hungary and Poland. Dahlerup also brings her political analysis home to Denmark, where she speaks about the intersection between politics of gender equity and xenophobia politics in Danish politics. Finally, the interview touches on Dahlerup's take on the \#MeToo movement, which she believes holds the potential to facilitate us in challenging old patriarchal structures and help renegotiate concepts of gender equality.

Following this interview, Signe Uldbjerg, PhD fellow at Aarhus University, addresses non-consensual sharing of intimate images or digital sexual assault in her article: "Writing Victimhood - A Methodological Manifesto for Researching Digital Sexual Assault." She captures the fact that victims often either are subjected to victim blaming or portrayed as 'broken' victims with little agency 
or hope of redemption. Through an experimental methodology based on creative writing, Uldbjerg strives to help victims find different voices by constructing their own alternative and empowering stories of victimhood. With this methodology, she combines activism and research in order to investigate digital sexual assault - actively supporting victims in constructing progressive stories of victimhood; stories that, as activism, work in opposition to oppressive discourses, and as research, offer insights into complex experiences of victimhood.

Professor Ana Prata based at California State University Northridge describes what the reception of the international \#MeToo movement has been like in Portugal. Her article uses a Black feminist framework and content analysis of newspaper data in order to trace the political process feminist movements engaged in when addressing gender-based violence. Her article "Caught in the Wave? Sexual Harassment, Sexual Assault, and the \#MeToo Movement in Portuguese Politics" further analyses how the \#MeToo movement contributed to the visibility and framing of the issues. She discusses which collective actions were pursued, and which outcomes were achieved. The findings show that the globalised \#MeToo movement has contributed to revitalise the Portuguese feminist movement, and that this vitality has led to more inclusive and intersectional activism.

PhD fellow Abeba Birhane based at the School of Computer Science at University College Dublin, and Postdoctoral Researcher Olivia Guest based at Donders Centre for Cognitive Neuroimaging, Radbourd University, Nijmegen in the Netherlands, contribute with an essay entitled "Towards Decolonizing Computational Science." In this essay, they guide us to how we might begin our journey towards decolonising computational research fields. They argue that we need to gain an awareness about how the current system has inherited and still enacts, hostile, conservative, and oppressive behaviours and principles towards women of colour, and that the solution to these inherited problems must be structural changes. With this essay they wish to advance a dialogue required to build both a grass-roots and a top-down re-imagining of computational sciences.

Elisabeth Bruun Gullach \& Maya Acharya, who are the founders of (Un)told Pages, has written an essay entitled: "Me, Who? (Un)telling Whiteness in Narratives of Sexual Violence," in which they draw attention to the ways in which white feminism has co-opted and 'whitewashed' the hashtag \#MeToo, ignoring the original intention of Tarana Burke to create a collective space for Black and Women of Colour to share experiences of sexual violence. In criticising how the \#MeToo movement has become indicative of white women's stories, Bullach and Acharya also show how Black, indigenous, and women of colour's experiences are erased or ignored in \#MeToo. They also point to similar trends within the larger feminist movement, within literature, and other arenas. They argue that when Black, indigenous, and women of colours' stories are shared, they follow a specific narrative of violence and trauma which casts Black, indigenous, and women of colour in a submissive and inferior role.

Marion Näser-Lather is a visiting researcher at the Helmut Schmidt University Hamburg and a private lecturer at the University of Marburg, who writes about the collaborations between 'gender-critic' scientists and right-wing Christian activists in Germany. In her essay "Academics against Gender Studies - Science populism as part of an authoritarian anti-feminist hegemony project," she uses discourse analysis to capture how 'gender-critic' scientists strive to lend 'scientific' authority to an authoritarian anti-feminist discourse which primarily is supported by male right-wing activists, Christian fundamentalists, and right-wing parties and movements. She argues that the scientists choice to support pseudo-scientific claims in their attempt to preserve conservative gender values and traditional gender roles unfortunately ends up undermining science as a whole. 
In activists Liv Moeslund Ahlgren and Ehm Hjorth Miltersen's essay, entitled "Overcoming the Implicit Resistance to Norm Critical Education", the authors describe their experiences with working for the Danish organisation "The Norm Stormers" (Normstormerne). The Norm Stormers teaches adolescents in Danish schools about how social norms are constructed and used to discriminate against LGBTQIA+ people and other minority positionalities. Working within an intersectional framework, the authors reflect upon the different types of resistances, both explicit and implicit, that they come up against in their work. They unpack how they work with students to identify norms in order to help them understand why and how we need to address and systematically change these social norms.

In author and consultant Mads Ananda Lodahl's essay, he poses the following question: "Is the Binary System a Biological Fact or a Social Norm?" (translated into English by Ehm Hjorth Miltersen and edited by Lea Skewes). In this essay, Ananda Lodahl highlights the conflicting norms which transgender and intersex people come up against in the Danish healthcare system. The essay situates the recent history of transgender and intersex legislation and activism, including the interrelated (but different) histories of the continued pathologisations of the two groups. This text is inspired by Anne Fausto-Sterling's (2000) iconic work

Sexing the Body in which she address how the biological body is physically molded to fit cultural gender norms and expectations.

\section{References}

Ahmed, S. (2007). A Phenomenology of Whiteness. Feminist Theory 8 (2), 149-168.

Ahmed, S. (2010). The Promise of Happiness. Durham and London: Duke University Press.

Ahmed, S. (2012). On Being Included - Racism and Diversity in Institutional Life. Durham and London:

Duke University Press.

Ahmed, S. (2017). Living a Feminist Life. Durham and London: Duke University Press

Anzaldúa, G., \& Moraga, C. (1981). This bridge called my back. Writings of Radical Women of Color. Persephone Press.

Astrup, S., \& Jensen, M. (2020, October 3). Få overblikket: Fra Linde til Jensen. \#Metoo-bølgen har nået stormstyrke. Politiken. Retrieved October 28, 2020, from https://politiken.dk/indland/art7946538/FraLinde-til-Jensen.-Metoo-bølgen-har-nået-stormstyrke

Bates, Laura (2014). Everyday Sexism. Simon \& Schuster.

Batty, D. (2020, Jun 11). Only a fifth of UK universities say they are 'decolonising' curriculum. The Guardian. Retrieved from: https://www.theguardian.com/us-news/2020/jun/11/only-fifth-of-uk-universities-have-said-they-will-decolonise-curriculum

Borchorst, A. \& Rolandsen Agustín, L (2017): Seksuel chikane på arbejdspladsen: Faglige, politiske og retlige spor. Aalborg: Aalborg Universitetsforlag.

Butler, J. (1990). Gender Trouble - Feminism and the Subversion of Identity. MY: Routledge Classics CBS (2017, Oct 17). More than 12M 'MeToo' Facebook posts, comments, reactions in 24 hours. CBS. Retrieved from: www.cbsnews.com/news/metoo-more-than-12-million-facebook-posts-comments-reactions-24-hours/.

Collins, P.H. (1989). The Social Construction of Black Feminist Thought. Signs, 14(4), 745-73. 
Collins, P.H. (1990). Black Feminist Thought: Knowledge, Consciousness and the Politics of Empowerment. Hyman.

Collins, P.H. (1998). It's All in the Family: Intersections of Gender, Race and Nation. Hypia 13 (3), 62-82.

Crenshaw, K. (1989). Demarginalizing the Intersection of Race and Sex: A Black Feminist Critique of Antidiscrimination Doctrine, Feminist Theory and Antiracist Politics. University of Chicago Legal Forum, 1(8).

Diep, F. (2020, Jun 9). 'I Was Fed Up': How \#BlackInThelvory Got Started, and What Its Founders Want to See Next. The Chronicle of Higher Education. Retrieved from: https://www.chronicle.com/article/I-WasFed-Up-How/248955

Enke, F. (2012). Introduction: Transfeminist perspectives. Transfeminist Perspectives in and Beyond Transgender and Gender Studies, 1-15.

Halberstam, J. (2017). Trans: A quick and quirky account of gender variability (Vol. 3). Univ of California Press.

Haraway, D. (1988). Situated Knowledges: The Science Question in Feminism and the Privilege of Partial Perspective. Feminist Studies, 14(3), 575-599.

Haraway, D. (1989). Teddy bear patriarchy taxidermy in the garden of eden, new york city, 1908-1936. In Primate visions: Gender, race, and nature in the world of modern science. New York: Routledge. 26-58.

Haraway, D. J., \& Goodeve, T. (1997).Modest_Witness@ Second_Millennium.FemaleMan_Meets_OncoMouse: feminism and technoscience. Routledge.

Haraway, D. J. (2016). Staying with the trouble: Making kin in the Chthulucene. Duke University Press.

Høg Utoft, E. (2020). Motivation, Organisational Gender Equality Work and the Postfeminist Gender Regime: A feminist approach. Aarhus: Politica.

Levy, R. \& Mattson, M. (2019). The Effects of Social Movments: Evidence from \#MeToo. Social Science Research Network. http://dx.doi.org/10.2139/ssrn.3496903

Mendes, K., Ringrose, J., \& Keller, J. (2018). \#MeToo and the promise and pitfalls of changing rape culture through digital feminist activism. European Journal of Women's Studies, 25(2), 236-246.

Mohanty, C. T. (1988). Under Western Eyes: Feminist Scholarship and Colonial Discourses. Feminist Review, 30, 49-74.

Namaste, V. (2000). Invisible Lives : The Erasure of Transsexual and Transgendered People. Chicago: University of Chicago Press.

Nielsen, M. W. (2017). Scandinavian Approaches to Gender Equality in Academia: A Comparative Study. In Scandinavia Journal of Educational Research, 61(3), 295-318.

Phipps, A. (2019). Every Woman Knows a Weinstein': Political Whiteness and White Woundedness in \#MeToo and Public Feminisms Around Sexual Violence. Feminist Formations, 31(2), 1-25.

Piscopo, J. (2019): The limits of leaning in: ambition, recruitment, and candidate training in comparative perspective. Politics, Groups, and Identities, 7(4), 817-828.

Possing, B. (2018). Argumenter imod kvinder - fra demokratiets barndom til i dag [Arguments Against Women - from the infancy of democracy until today]. Strandberg Publishing.

Prosser, J. (1998). Second skins: The body narratives of transsexuality. Columbia University Press

Raun, T. (2014). Trans as Contested Intelligibility. Lambda Nordica, 19(1), 13-37.

Skewes, L., Fine, C., \& Haslam, N. (2018). Beyond Mars and Venus: The role of gender essentialism in support for gender inequality and backlash. PlosOne. https://doi.org/10.1371/journal.pone.0200921

Skewes, L., Skewes, J. C., \& Ryan, M. K. (2019). Attitudes to Sexism and Gender Equality at a Danish University. Kvinder, Køn \& Forskning, 28(1-2), 71-85.

Skewes, L., Skewes, J. C., \& Ryan, M. K. (accepted). Attitudes to Sexism and the \#MeToo Movement. Nordic Journal of Feminist and Gender Research.

Spivak, G. (1981). French Feminism in an International Frame. Yale French Studies, (62), 154-184. doi:10.2307/2929898 
Spivak, G. (1988). Can the Subaltern Speak? In C. Nelson and L. Grossberg (Eds.). Maxism and the Interpretation of Culture (pp. 271-371). Urbana: University of Illinois Press.

Staunæs, D. (2005) From Culturally Avant-garde to Sexually Promiscuous: Troubling Subjectivities and Intersections in the Social Transition from Childhood into Youth.

Feminism \& Psychology, 15(2), 149-167.

Stone, S. (1987). The empire strikes back: A posttransexual manifesto.

Stryker, S (1994). My Words to Victor Frankenstein Above the Village of Chamounix: Performing Transgender Rage. GLQ: A journal of lesbian and gay studies , 1(3), 237-254.

Stryker, S. (1998). The transgender issue: An introduction. GLQ: A journal of lesbian and gay studies, 4(2), 145-158.

Stryker, S. (2006). (De)Subjugated Knowledges: An introduction to transgender studies. In S. Stryker \& S. Whittle (Eds.). The transgender studies reader $1,1$.

Swim, J. K., Aikin, K. J., Hall, W. S., \& Hunter, B. A. (1995). Sexism and Racism: Old-Fashioned and Modern Prejudices. Journal of Personality and Social Psychology, 68(2), 199-214. 